
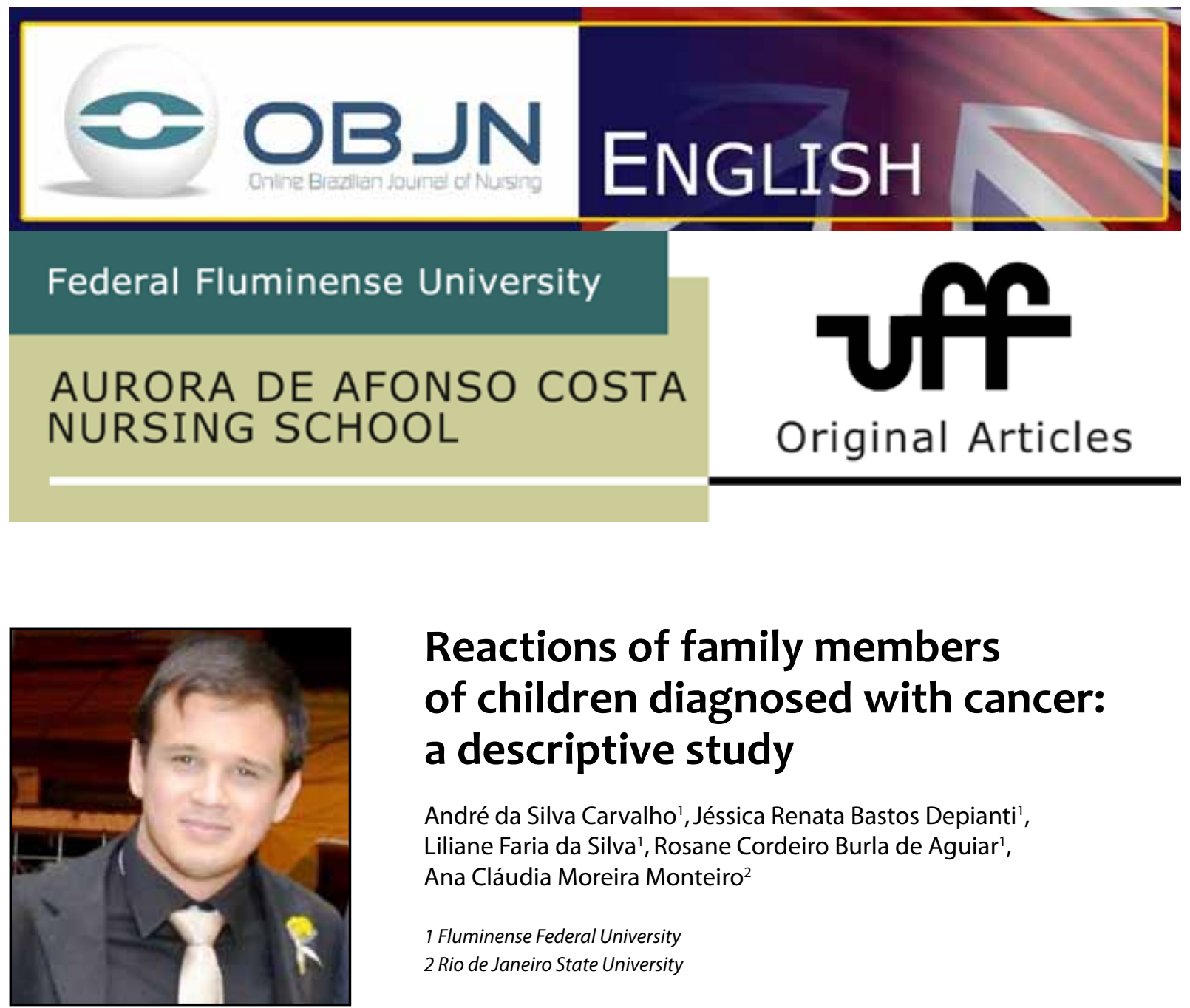

\title{
Reactions of family members of children diagnosed with cancer: a descriptive study
}

\author{
André da Silva Carvalho', Jéssica Renata Bastos Depianti', \\ Liliane Faria da Silva', Rosane Cordeiro Burla de Aguiar', \\ Ana Cláudia Moreira Monteiro² \\ 1 Fluminense Federal University \\ 2 Rio de Janeiro State University
}

\section{ABSTRACT}

Aims: to identify the reactions of relatives after a diagnosis of pediatric cancer; to describe the work of the nursing team based on these reactions; to analyze the expectation of the family regarding nursing care based on the diagnosis of pediatric cancer. Method: this is a qualitative, descriptive research performed in an onco-hematologic ward located in the state of Rio de Janeiro, Brazil. For data collection, semi-structured interviews were used. Results: this study generated some thematic units: the reactions of relatives based on the diagnosis of pediatric cancer; the work of the nursing team based on the reactions of the family of the child with the diagnosis of cancer; expectation of the relatives regarding the work of the nursing team on the relatives of the child with cancer. Discussion: relatives have feelings such as despair, fear of death, guilt, revolt and denial, making it necessary to include the relatives in nursing care procedures. Conclusion: to provide for the necessities of the relatives, caring must provide comfort, support, and a clear communication about the illness, in order to minimize their suffering.

Descriptors: Oncologic Nursing; Family; Child. 


\section{INTRODUCTION}

Cancer is a term that defines a set of various diseases that have one thing in common, which is the disorganized growth of malignant cells. These cells invade other tissues and organs, being able to spread out to other parts of the body, which can develop to a metastasis. While tumors in adults are usually related to the exposure to many external factors, such as smoking, dietary habits, alcoholism, medication, and other occupational factors, during childhood, the causes are less known. ${ }^{(1)}$

The diagnose of pediatric cancer causes a great impact on a child's and the child's relatives' lives, being characterized as a devastating occurrence, capable of generating unexpected changes and reactions, not only on the life of those who have the diagnosis, but also on the closest relatives. ${ }^{(2)}$

The child diagnosed with cancer and his relatives are faced with stigmas and myths originating from this disease, producing impacts on these subjects, such as reactions of protest, despair, and denial, causing a shock based on the diagnosis of the illness. ${ }^{(3)}$

Parents see the diagnosis and the treatment against cancer in a different perspective, despite the fact both parents share the same suffering. On many occasions, the mother takes the role of main caregiver of the child during hospitalization ${ }^{(4)}$, hence she is more exposed to the stress of the process of treatment of the child.

The diagnosis of cancer during childhood can originate difficulties of communication between parents, health professionals and children during the treatment against the pathology. Many times, parents do not clarify the diagnosis for their children, or they can even omit information about the general health condition of the child to the professionals. ${ }^{(5)}$
Based on the information here demonstrated, it is observed that the diagnosis of pediatric cancer generates anguish for both the child and his family, and this leads to a confrontation of the problems inherent to the disease, to the treatment, and to the changes of the daily routines of all people involved. Therefore, the nurses have a fundamental role in the caring for these subjects, as they work in direct assistance to both, generating an improvement in quality of life. ${ }^{(6,7)}$

It is known that cancer also generates adverse effects due to the chemotherapeutic elements of the treatment, but it also affects the psychosocial side, provoking sadness, anger, depression, and other states. Therefore, to minimize these effects, it is necessary that there is support from a multiprofessional team that helps the child and his family, transforming the treatment to a less impactful approach, improving the quality of life of the subjects involved. ${ }^{(8)}$

Even experiencing the shock of the revelation of pediatric cancer, the family needs to have a reaction in order to continue with the caring and the treatment of the child, as cancer demands the necessity to adapt to support the many specific conditions of the treatment protocols, such as examinations, consultations, and hospitalizations. ${ }^{(2)}$

The understanding of the disease and treatment implemented by the relatives after the confirmation of diagnosis is fundamental to achieve the adherence of these subjects, as during this stage of life, the child is even more dependent on his relatives ${ }^{(2,9)}$. On the other side, the nurse must know the possible reactions of the relatives after the diagnosis of pediatric cancer, as well as their expectations regarding the care given to the child. Hence, it is possible to establish an assistance directed to the child's real necessities.

Based on the questions presented, this study was limited to the subject of the work of the 
nursing team based on the reactions of relatives with the diagnosis of pediatric cancer.

The following guiding questions were drawn up: what are the reactions of the relatives after the diagnosis of pediatric cancer? How does the nursing team work with these relatives based on their reactions? What are the expectations of the relatives regarding nursing care based on the diagnosis of pediatric cancer?

The aims of this research were: to identify the reactions of the family based on the diagnosis of pediatric cancer; to describe the work of the nursing team based on these reactions; to analyze the expectations of relatives related to nursing care over the diagnosis of pediatric cancer.

\section{METHOD}

This is a descriptive study, with a qualitative approach. ${ }^{(10)}$ The chosen scenario was the onco-hematological ward of a public hospital located in the Brazilian state of Rio de Janeiro, which attends to the needs of children, adolescents and adults with cancer, such as leukemia and lymphoma.

The subjects were seven relatives of children in oncological treatment, being one relative per child. Despite the fact there was no preference for a particular degree of relationship between the relative and the child, it is important to mention that all interviewees were the mothers because they were the ones keeping company with the children at the ward. The criteria of inclusion of the subjects were: being a relative of a child diagnosed for at least six months with cancer, as after this period the initial moment of diagnosis and treatment is already in place; relative must be eighteen years old or above; the interviewee must be in touch with the child during the person's daily routine. The relatives of children under palliative care were excluded, as this is a very delicate moment for the child and for the family.

The number of participants was determined during the process of transcription and analysis of data, and the organization of the testimonies throughout the research in the field permitted to identify the empiric saturation of data, or in other words, the reoccurrence of testimonies, standards of behavior, practices, and views of the world ${ }^{(11)}$. It is important to clarify that two criteria were used to finish the fieldwork process. The first criterion was based on the internal validity of the research, which aimed to find the empiric saturation of data; the second criterion supported the external validity ${ }^{(11)}$, comparing the number of participants of this research with the number of participants of other studies with a qualitative approach, developed with relatives of children with cancer. Some studies were found, with the number of participants varying from six ${ }^{(12)}$ to sixteen. ${ }^{(13)}$

Data collection was performed from April $16^{\text {th }}$ to April $27^{\text {th }} 2012$, in the morning, four hours a day, in a total of 40 hours. To collect the information, the semi-structured interview was used; during the interviews, an interview guideline helped to organize the open-ended and closed questions required by the study.

Initially, only closed questions were asked, which were important to identify the subject, and to bring up some of their characteristics. Later, the following open-ended questions were asked: how did you feel when you heard the diagnosis of child cancer? How was the work of the nursing team during the moment of diagnosis of child cancer? How do you think the nursing team can help the family during the moment of diagnosis of child cancer?

To have an accurate and precise record of the testimonies given, the interviews were recorded with an mp3 recorder, based on previous 
authorization by the subjects. The anonymity of the participants was ensured at all times, and because of that, alphanumeric codes were used to identify the interviewees.

The words of the subjects were fully transcribed, and the data examined though thematic analysis. The following steps were taken according to the analytical method: floating reading through an exhaustive contact with the material; exploitation of the material, in which after the reading of the raw information, the testimonies were grouped to the pre-established thematic units that provided answers to the aims and the hypothesis raised in this research; and finally, the treatment and interpretation of the results found. ${ }^{(6)}$

According to Resolution 466/2012 of the Brazilian National Health Council, which defines the directives and regulatory standards of researches involving human beings, this research project was previously submitted and approved by the Committee of Ethics in Research of the hospital in which it was performed (Protocol \#276/11).

\section{RESULTS}

From the answers of the interviewed relatives, the following thematic units arose: the reactions of the family based on the diagnosis of pediatric cancer; the work of the nursing team regarding the reactions of the family based on the diagnosis of pediatric cancer; the expectations of the family regarding the work of the nursing team towards the relatives of the child with cancer.

The reactions of the family based on the diagnosis of pediatric cancer

When answering the question regarding their own reaction after the confirmation of the diagnosis of pediatric cancer, the following answers were given:

\begin{abstract}
When she (the pediatrician) said it, I had no reaction, but when I left, I sat and said: cancer, my God! Leukemia! (...) Then I started crying, got desperate, really desperate and very sad. (M-02)
\end{abstract}

\begin{abstract}
At the moment we are informed about the diagnosis, we are powerless, right? Some kind of lost, without knowing what to do (M-05).
\end{abstract}

\begin{abstract}
Gee, my world came down, you know? It was horrible; I think it was the worst news I could get. It was really awful. (M-03).
\end{abstract}

It is seen that the moment of informing the relative of the diagnosis leads to despair and sadness, as they feel "powerless", and the first moment after this they report feeling lost and needing time to understand what is being said, in order to "come back". In this sense, it is noticeable that the relative only understands that the child has cancer after they leave the premises where the professional is located (office, ward, hospital).

When they learn the diagnosis of pediatric cancer, they think of the possibility of death and the loss of the child:
You think that cancer is like: my child has cancer... He's going to die soon, maybe today! (M-05).

Well, you picture that the child will die (...) you can't think of anything else, you know? (...) on the first impact, that's what comes to your mind. (M-06). 
When given the diagnosis of pediatric cancer, the fear of death and rapid loss of the child was present in the testimonies of the relatives, and this fact reinforces the idea of the stigma cancer has as an acute disease, without a cure, and associated with quick and inevitable death.

The relatives reported they searched for help from their faith to support the diagnosis of pediatric cancer:

Faith is something enormous (...) I'm closer to God now, and I placed my son on His hands. (M-04)

I have lots of faith, and I strongly believe in Jesus, you know? So I'm closer to my faith, to my prayers! (M-05).

We have to trust in God, you know? (M-06)

The belief that cancer is an incurable disease and directly associated with a quick death can be a determinant that relatives need to get strongly connected to their religious faith and search for support in their prayers.

Another aspect mentioned by the subjects was the necessity to empower themselves in order to provide some empowerment for the child, hence helping the child to face the illness.

I need to give him a hand, you know? So, we have to be strong, and even when it's too difficult, at the moment we are with the child we must be strong, so they can follow our lead. (M-03).

I had to be strong even to give support to my child. He needed to fight, he needed to believe that this all will be gone someday (...) because I knew I had to fight, that I had to give him strength to fight against this disease (M-05).

The relatives recognize the necessity to be on the side of the child, transmitting trust and strength to help the child to continue and to confront the disease and the treatment. This necessity to be together was motivated so that even after the presentation of the diagnosis the relatives remain strong to support the child.

The work of the nursing team regarding the reactions of the family based on the diagnosis of pediatric cancer

When questioned about the work of the nursing team at the time they were informed about the condition of pediatric cancer, the relatives responded:

When we found out about his condition, I was hospitalized for a long time here at the hospital, for a month or so. They (the nursing team) helped me, gave me attention, care, they also talked with me and with him (the child). I felt love for them (M-02).

At any moment the nursing team hid what was going on (...) she told me what was the diagnosis, didn't try to hide anything. They gave me lots of support, comfort (...) I had all sorts of information regarding the disease (M-01).

They always explained which medication they were using and why (...) they were always optimistic and tried to give as much information about the illness as I wanted, calming me down in the moments when I was desperate (...) 
like guardian angels (...) always explaining me what was happening (M-05).

It is a moment that sometimes we are by ourselves (...) but there is a really strong support coming that makes you feel that you are not completely alone (...) there is always a nurse there to help (M-07).

When my sisters came to visit, they had a word with them (the nursing team). The professionals explained and oriented about everything (M-03).

It is possible to see, from the testimonies of the subjects, that communication is essential to better provide nursing care to the relatives of the child with cancer. The testimonies focused on the conversation between the nursing team and the relatives, in which the professionals demonstrated support and orientation regarding the illness and the treatment the child would be submitted to during the administration of drugs.

The orientation was also given to other relatives and family members during the visits, and not only to the accompanying relative. This proximity, the conversation, the support given and the orientation helped the relatives to not feel alone in facing the struggle.

The subjects also mentioned the work of the team based on the behavior of the children:

My son is quite mischievous, and when I call his attention, they come to me and say: let him play! He's just a kid! They were always caring, always helpful. (M-02).

Once my son kicked a nurse at the moment she was giving him a shot (...) I though she was going to get mad at him (...) but she had a talk with him, explained why, that she wasn't doing any harm (...) that she felt sorry for the shot, but it was extremely necessary. She explained everything to him (M-05).

They work with lots of love and care. They try not to make too many holes, trying to pierce the correct spot to not hurt the child (M-05).

Nursing professionals try to interact with the children and they understand the time the patients are being put through. They stimulate the relatives to let the children play, explain before starting a procedure, telling the child the necessity of each step, and beside that, the nurses avoid repetitive venous punctures, which characterizes a less traumatic care service for the child.

Based on the views of the relatives, in nursing care there is a preoccupation to comfort the accompanying relative, as well as other relatives, during hospital visits, and the members of the family report that it makes them feel supported. The talks and explanations are also given to the children under oncological treatment, so they understand the necessity to perform certain proceedings.

Expectations of the family regarding the work of the nursing team towards the relatives of the child with cancer

The third thematic unit that arose from the testimonies of the subjects was linked to the expectations that relatives have regarding the work of the nursing team towards the family members when they are informed about the diagnosis of pediatric cancer:

I think that they (the nursing team) must be close to the family (...) saying 
something to give some comfort, to reduce the stress $(M-01)$.

Always focusing on the family, giving support any way possible, because I don't see only the professional, but also the human being (...) they participate, give, and cry by your side, trying to understand you (...) I only want to ask them to keep up this way forever (M-05).

They need to be caring, giving attention, because we are too sensitive (M-06).

Among the expectations of the relatives, they call attention to the fact that the nursing team must be close to the family, and then provide comfort, care and support. This approximation enables the relatives to be less stressed, even during moments of emotional fragility.

Two subjects mentioned that, among their expectations regarding the work of the nursing team, there is also the sharing of information:

I think they could work sitting down, talking, explaining things. Explaining everything, opening for dialogue $(M-$ 02).

Transmitting what they know (...) chemotherapies have many different names, and there are things we don't know the reactions to (...) there was a chemotherapy section that I wanted to know the name of, which had a certain reaction... But there were many, you know? (M-05)

In the beginning of the treatment, relatives and children are exposed to a new universe that is not part of their everyday lives, in which they face chemotherapeutic medication, with unknown names and reactions, and because of that, they feel the necessity for the nursing team to be ready to dialogue, to listen to their doubts, and to respond to whatever they feel is necessary to be answered.

\section{DISCUSSION}

The findings of this research corroborate with other studies that have analyzed the reactions of relatives originated by the diagnosis of pediatric cancer. These same studies identified that the majority of relatives experience despair, fear of death, guilt, revolt and denial. ${ }^{(14)}$ The identification of the diagnosis of pediatric cancer causes, especially among mothers, an avalanche of emotions, which initially do not have an explanation and are characterized by shock, despair, surprise and fear. ${ }^{(2)}$ When receiving the diagnosis of pediatric cancer, the family goes through a moment of denial, feels fragile, and requires support. The nursing team must be aware that they should offer help to the relatives, to empower these people to overcome this moment of pain. ${ }^{(15)}$

Despite the fact that the chances of cure of pediatric cancer are high, which is also aided by early diagnosis and the development of the types of treatment, it is seen, from the testimonies of the subjects, that the disease is linked to the possibility of death.

Even with the knowledge that there is a possibility of cure, it is evident that cancer is a pathology that carries a socially-built stigma comparing it to a death sentence. When dealing with pediatric cases, death is also wrapped in a layer of cruelty, because children are the living synonyms for joy, growth and plans for the future. This possibility of death of the child requires parents to believe that intensive care 
and protection may postpone the end of life, and even knowing there is a chance of cure, the idea of life threat prevails. ${ }^{(2)}$

When planning the caring procedures, the feeling that relatives have regarding the illness need to be taken into consideration, in order to exchange information, orientations and clarifications about the types of treatment to be used. The treatment will, in the end, contribute to the development of the abilities and capacities of the nurses when fighting the disease. This requires that the professionals promote health education at the same time as they provide caring assistance, based on the assumption that relatives are an important source of support and well-being for the ill person, especially for the child with cancer. ${ }^{(16)}$

In the testimonies collected, it is noticeable that the subjects got closer to their spirituality. Therefore, when the divine entity dominates the life of men, the unexpected, which in this case is the cancer, is explained and the fatality gives way to the safety contained into divine providence. ${ }^{(13)}$ Then, the relatives feed themselves with hope, and they trust in the religious faith they have.

When hearing the diagnosis of pediatric cancer, everything seems unreal and unbelievable, and because of that, the relatives spend some time without understanding what is really happening. However, there is a moment when they need to react and to search for some sort of strength, despite the feeling of sadness. They see that nothing more can be done to avert the situation, and they need to be strong in order to give some strength to their children. ${ }^{(2)}$

During the caring procedures for the child with cancer and his relatives, the nursing professionals get involved in the routine to perform such routines, and besides that, develop activities of orientation for children and their relatives about the disease and the hospital environment, combining their understanding and their technical abilities with solicitude, filled with sensitivity and availability to be closer to the needs, anxieties and fears experienced by the relatives, thus identifying a necessity of intervention by other health professionals. ${ }^{(17)}$

Nursing care, in this context, is complex, because it transcends the technical care procedures, and is expressed by the attitudes seen in the relationship with the children and their relatives. The nurse is responsible for promoting a care that is centered in the child and his family, and for establishing an effective communication with the relatives, as they are essential to a holistic promotion and assistance to the health of the child. ${ }^{(3,7)}$

Communication is a means of exchange of information that works both in verbal and non-verbal modes. It is important that nursing is seen to promote support and that it is recognized as a therapeutic tool, which aims to create closer bonds between the nurse, the child and the relatives ${ }^{(16)}$. It is a good opportunity for the nurse to develop a strategy of education of health with the relatives in order to promote orientations about health and the care of children who are still in hospitalization. ${ }^{(18)}$

As caring is the essence of nursing, this action must reflect a preoccupation with the other, establishing bonds of affection and fondness, promoting manifestations of support and understanding for both the child and the relatives, to strengthen all their relationships. ${ }^{(7)}$

Another aspect mentioned by the relatives was the work of the team based on the behavior of the children. For them, it is important that the professionals understand the time they are going through, and try to offer less traumatic care procedures. This data corroborates with researches that call attention to the fact that it is necessary to consider the singularities and the stages of development of each child, because he needs help and the least hostile environment possible, where nursing and the members of the 
health team can invest their efforts to help in this critical event, making themselves closer to the patient/accompanying subjects. ${ }^{(17,19,20)}$

Among the expectations that relatives have regarding the work of the nursing team, there is an emphasis on communication, with exchange of information and orientation. Communication is one of the most important instruments in the relationship between the child, the relatives and the nurse. However, communication is much more than a simple instrument to acquire information; it is a process that must involve a series of abilities, attitudes, and positions that include a biopsychosocial view of the human being in a much wider way. ${ }^{(15)}$

In the context of nursing, verbal communication is frequent and evident, expressed by the verbalization of words, note taking, and registry in medical records. However, many nursing professionals limit themselves to this aspect and forget to develop the complete process, such as non-verbal language, which involves the expression of feelings, gestures and touch ${ }^{(15)}$. These other dimensions, in non-verbal language, were mentioned by the relatives as some of the expectations they have of the nursing team.

\section{CONCLUSION}

The diagnosis of pediatric cancer generates suffering for both the child and his relatives, forcing them to confront problems related to the evolution of the disease itself, the ambulatory treatment, the long hospitalization periods, and the changes in lifestyle.

After the confirmation of diagnosis of pediatric cancer, relatives go through many stages. Initially they feel lost, without properly understanding the situation, and when they finally are aware that their child has cancer, they become desperate and sad. They associate the diagnosis to death, and because of that, search for support in their own religion, to empower themselves to give some strength and support to the child who is dealing with the illness and the treatment.

In the caring for the child and the relatives, the nursing team must work in a way that provides support and comfort. It is necessary that there is a clear communication with the family, with exchange of information, explanations and orientation about the disease. With regard to the child, it is necessary to understand the reactions when performing the required caring and proceedings, minimizing their suffering as much as possible.

Among the expectations of the family with regard to the care of the nursing team, actions that will generate comfort, care and support are the most needed, as well as the provision of information using active listening, dialogue and explanations about the pathology, the treatment and the necessary care to provide for the needs of the children under oncologic treatment. These expectations express the necessity of caring in a more humanized way.

\section{REFERENCES}

1. Instituto Nacional do Câncer (Brasil). Ações de enfermagem para o controle do câncer: uma proposta de integração e serviço. Instituto Nacional do Câncer. 3.ed. Rio de Janeiro: INCA; 2008.

2. Santos LMP, Gonçalves LLC. Crianças com câncer: desvelando o significado do adoecimento atribuído por suas mães. Rev. enferm. UERJ, 2008 Apr/ Jun; 16(2): 224-9.

3. Avanci BS, Carolindo FM, Góes FGB, Netto NPC. Cuidados paliativos à criança oncológica na situação do viver/morrer: a ótica do cuidar em enfermagem. Esc Anna Nery. 2009; 13(4): 708-16.

4. Silva FM, Jacob E, Nascimento LC. Impact of Childhood Cancer on Parents' Relationships: An Integrative Review. Journal of Nursing Scholarship, 2010; 42(3): 250-261.

5. Gibson F, Aldiss S, Horstman M, Kumpunen S, Richardson A. Children and young people's ex- 
periences of cancer care: A qualitative research study using participatory methods. International Journal of Nursing Studies, 2010;47: 1397-1407.

6. Silva, LF, Cabral, IE, Christoffel, MM. As (im)possibilidades de brincar para o escolar com câncer em tratamento ambulatorial. Acta Paulista de Enfermagem, 2010; 23(3): 334-340.

7. Monteiro ACM, Rodrigues BMRD, Pacheco STA. O enfermeiro e o cuidar da criança com câncer sem possibilidade de cura atual. Esc. Anna Nery. 2012;16(4):741-746

8. Balogh EP, Ganz PA, Murphy SB, Nass SJ, Ferrell BR, Stovall E. Patient-Centered Cancer Treatment Planning: Improving the Quality of Oncology Care. Summary of an Institute of Medicine Workshop. The Oncologist. 2011;16:1800-1805.

9. Silbermann $M$, Arnaout $M$, Daher $M$, Nestoros $S$, Pitsillides B, Charalambous H, Gultekin M, Fahmi R, Mostafa KAH, Khleif AD, Manasrah N, Oberman A. Palliative cancer care in Middle Eastern countries: accomplishments and challenges. Annals of Oncology, 2012 Apr; 23(3): 15-28.

10. Minayo MCS. Los conceptos estructurantes de la investigación cualitativa. Salud Coletiva. 2010; 6(3): 251-61.

11. Fontanella BJB, Ricas, J, Turato, ER. Amostragem por saturação em pesquisas qualitativas em saúde: contribuições teóricas. Cad. Saúde Pública, Rio de Janeiro, 2008 Jan; 24(1): 17-27.

12. Di Primio AO, SchwartzE, Bielemann VLM, Burille $A$, Zillmer JGV, Feijó AM. Rede social e vínculos apoiadores das famílias de crianças com câncer. Texto Contexto - Enferm. 2010 Apr/Jun; 19 (2): 334-342.

13. Malta, JDS; Schall VT; Modena C. M. Câncer pediátrico: o olhar da família/ cuidadores. Pediatr. Mod. 2008; 44(3):114-8.

14. Silva, FAC, Andrade, PR, Barbosa, TR, Hoffmann, MV, Macedo, CR. Representação do processo de adoecimento de crianças e adolescentes oncológicos junto aos familiares. Esc Anna Nery Ver. Enferm. 2009 Apr-Jun; 13(2): 334-41

15. Rodrigues MVC, Ferreira, ED, Menezes, TMO. Comunicação da enfermeira com pacientes portadores de câncer fora de possibilidade de cura. Rev. Enferm. UERJ, Rio de Janeiro, 2010, Jan/Mar 18(1): 86-91;

16. Paiva RS, Valadares GV, Pontes JS. The need to become family caregivers: qualitative study focusing on the theory based on data. Online braz j nurs [Internet]. 2012 Dec [cited Mar 23 2013]; 11 (3):607-20. Available from: http://www.objnursing.uff.br/index.php/nursing/article/view/3638

17. Carneiro DMS, Souza IEO, Paula CC. Cotidiano de mães-acompanhantes de-filhos que foram a óbito: contribuições para a enfermagem oncológica. Esc Anna Nery. 2009; 13(4): 757-62.

18. Beuter M, Brondan CM, Szaresk C, Lana LD, Alvim N AT. Perfil de familiares acompanhantes: contribuições para a ação Educativa da enfermagem. Rev. Min. Enferm. 2009 Jan/Mar; 13(1): 28-33.

19. Gilmour J, Harrison C, Asadi L, Cohen MH, Vohra S. Hospitals and Complementary and Alternative Medicine: Managing Responsibilities, Risk, and Potential Liability. Pediatrics, 2011 Nov; 128(4): 193-199.

20. Peña ALN, Juan, LC. A experiência de crianças hospitalizadas sobre sua interação com os profissionais de enfermagem. Rev. Latino-Am. Enfermagem, 2011 Nov/Dec; 19(6).

All authors participated in the phases of this publication in one or more of the following steps, in According to the recommendations of the International Committee of Medical Journal Editors (ICMJE, 2013): (a) substantial involvement in the planning or preparation of the manuscript or in the collection, analysis or interpretation of data; (b) preparation of the manuscript or conducting critical revision of intellectual content; (c) approval of the versión submitted of this manuscript. All authors declare for the appropriate purposes that the responsibilities related to all aspects of the manuscript submitted to OBJN are yours. They ensure that issues related to the accuracy or integrity of any part of the article were properly investigated and resolved. Therefore, they exempt the OBJN of any participation whatsoever in any imbroglios concerning the content under consideration. All authors declare that they have no conflict of interest of financial or personal nature concerning this manuscript which may influence the writing and/or interpretation of the findings. This statement has been digitally signed by all authors as recommended by the ICMJE, whose model is available in http://www.objnursing.uff.br/ normas/DUDE_eng_13-06-2013.pdf

Received: 04/26/2013

Revised: 06/09/2014

Approved: 06/16/2014

Carvalho AS, Depianti JRB, Silva LF, Aguiar RCB, Monteiro ACM. Reactions of family members of children diagnosed with cancer: a descriptive study. Online braz j nurs [internet] 2014 Sep [cited year month day]; 13 (3):282-91. Available from: http:// www.objnursing.uff.br/index.php/nursing/article/view/4356 